\title{
Synthetic studies towards the novel fomannosane sesquiterpenoid illudosin: framework construction
}

\author{
Goverdhan Mehta* and K. Sreenivas \\ Department of Organic Chemistry, Indian Institute of Science, Malleshwaram, Bangalore 560012, India
}

\begin{abstract}
A synthetic approach to the novel fomannosane sesquiterpene natural product illudosin $\mathbf{2}$ from the diquinane precursor $\mathbf{5}$, readily available in turn from commercial 1,5-cyclooctadiene, is delineated. The key steps are the stereoselective construction of the cis, anti, cistricyclo[6.2.0.0 $\left.0^{2,6}\right]$ decane system, strategic $\mathrm{C}-\mathrm{C}$ bond disengagement through Baeyer-Villiger oxidation and functional group adjustments to deliver the carbocyclic core $\mathbf{1 8}$ present in the natural product.
\end{abstract}

Cyclobutane containing natural products have been encountered infrequently in nature and therefore any new addition to this group draws special attention. In 1967, a novel cyclobutane containing natural product fomannosin 1 was isolated from the wood-rotting fungus basidiomycetes Fomes annosus (Fr.) Karst ${ }^{1 \mathrm{a}, \mathrm{b}}$ and subsequently from Fomitopsis $_{\text {insularis }}{ }^{1 \mathrm{c}}$ and its unique stereostructure was deduced through extensive spectral studies and X-ray crystallography. ${ }^{\text {a,b }}$ Subsequently in $1991^{2 \mathrm{a}}$ and more recently in $1999^{2 b}$ and $2000,{ }^{2 c}$ the same fomannosane carbocyclic framework has been encountered in another sesquiterpene natural product illudosin $\mathbf{2}$, from the basidiomycets Omphalotus illudens (O. illudens) ${ }^{2 \mathrm{a}}$ and $O$. nidiformis, ${ }^{2 \mathrm{~b}}$ respectively. It has been proposed that $\mathbf{1}$ and $\mathbf{2}$ are biosynthetically derived from farnesyl pyrophosphate via the humulyl and protoilludyl cations $\mathrm{s}^{2 \mathrm{~b}}$ and illudosin $\mathbf{2}$ is the likely precursor of fomannosin $1 .^{2}$ While fomannosin has been found to be toxic toward Pinus tadea seedlings, Chlorella pyrenoidosa and some bacteria, ${ }^{3}$ illudosin has been shown to exhibit antibacterial activity against Basillus subtilis and genotoxic activity against Escherichia coli. ${ }^{2 \mathrm{c}}$ The novel architecture, dense oxyfunctionalisation and interesting biological activity of $\mathbf{1}$ and
2 has attracted the attention ${ }^{4,5 a, b}$ of synthetic chemists and the total synthesis of fomannosin $\mathbf{1}$ by Semmelhack et al. has been a notable achievement. ${ }^{4}$ However, no synthetic efforts towards illudosin 2, the other member of the fomannosane family, have been reported so far.

Recently, we have accomplished the total synthesis of cyclobutane containing sesquiterpenoids like kelsoene ${ }^{6}$ and sulcatine $\mathrm{G}^{7}$ which embody cis, anti, cis-tricyclo[6.2.0.0 $\left.0^{2,6}\right]$ decane system $\mathbf{3}$ as the common core. It occurred to us that strategic $\mathrm{C}-\mathrm{C}$ cleavage in the 5-5-4 fused system 3 could lead to $\mathbf{4}$, the framework present in fomannosin $\mathbf{1}$ and illudosin 2, Scheme 1. Retrosynthetic analysis on illudosin 2 along this theme led to the identification of the diquinane $\mathbf{5}$ as the key precursor, tricyclic ketone $\mathbf{6}$ as the key intermediate and $\mathbf{7}$ as the pre-target having the complete $\mathrm{C}_{15}$-carbon skeleton of $\mathbf{1}$ and $\mathbf{2}$ and requisite functionality for elaboration to the natural product, Scheme 2. The cis, anti, cis stereochemical pattern present in $\mathbf{6}$ was meant to ensure the generation of requisite stereochemistry in the connectivity between the four and the five-membered rings of $\mathbf{1}$ and $\mathbf{2}$. It was envisaged that allylic oxidation in $\mathbf{7}$ would introduce the aldehyde and hydroxy functionalities present
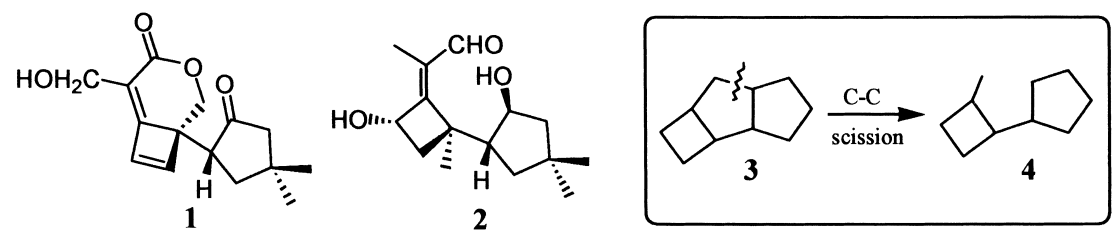

Scheme 1.

Keywords: Baeyer-Villiger oxidation; farnesyl pyrophosphate; cyclobutanoids; photocycloaddition; enone transposition.

* Corresponding author. Tel.: +91-80-3942850; fax: +91-80-3600936; e-mail: gm@ orgchem.iisc.ernet.in 


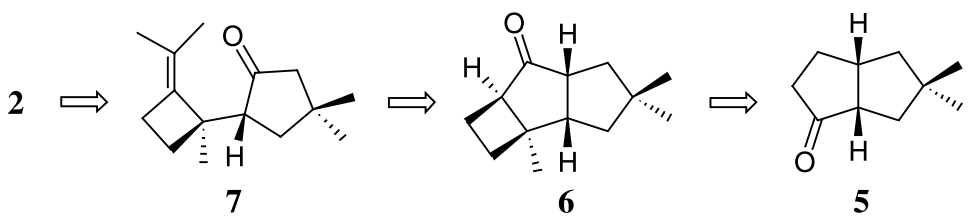

Scheme 2.
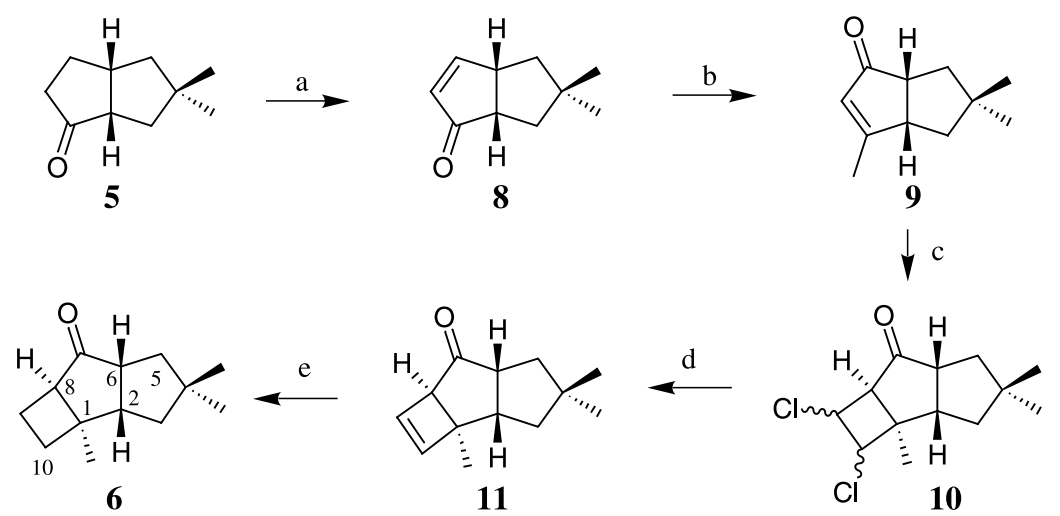

Scheme 3. Reagents and conditions: (a) i. LHMDS, TMSCl, THF, $-78^{\circ} \mathrm{C}$ to rt, $2 \mathrm{~h}$, ii. $\mathrm{Pd}(\mathrm{OAc})_{2}, \mathrm{CH}_{3} \mathrm{CN}, \mathrm{rt}, 4 \mathrm{~h}, 82 \%$; (b) i. $\mathrm{MeLi}$, ether, $0^{\circ} \mathrm{C}, 15 \mathrm{~min}, 92 \%$, ii. PCC, $\mathrm{CH}_{2} \mathrm{Cl}_{2}, \mathrm{rt}, 2 \mathrm{~h}, 85 \%$; (c) trans-1,2-dichloroethylene, cyclohexane, $h \nu$, pyrex, $4.5 \mathrm{~h}, 93 \%$; (d) i. ethylene glycol, PTSA, benzene, reflux, 24 h, $80 \%$, ii. $\mathrm{Na}^{+} \mathrm{C}_{10} \mathrm{H}_{8}^{-}$, DME, rt, 30 min, $95 \%$, iii. Amberlyst-15, acetone, rt, 10 h, 87\%. (e) $\mathrm{H}_{2}, \mathrm{PtO}_{2}$, EtOAc, 2 h, $97 \%$.

in illudosin 2 and for which enough precedence exists in the literature. ${ }^{8}$ Herein, we report a stereoselective construction of a derivative of 7 from readily available starting materials.

We have recently described the synthesis of the diquinane 5 from commercially available 1,5-cyclooctadiene. ${ }^{7 \text { a }}$ Diquinane $\mathbf{5}$ was first elaborated to the enone $\mathbf{8}$ following the Saegusa procedure of trimethylsilylenol ether formation and $\mathrm{Pd}(\mathrm{II})$ mediated dehydrogenation. ${ }^{9}$ Enone 8 was subjected to alkylative enone transposition via MeLi addition and PCC oxidation to yield 9. ${ }^{10}$ The diquinane enone 9 was now poised for the annulation of a four membered ring through the olefin-enone [2+2]-photocycloaddition. Irradiation of enone 9 in the presence of trans 1,2-dichloroethylene led to the formation of [2+2]addition products $\mathbf{1 0}$ as a mixture (vide Section 1) of cisand trans-1,2-dichloro-isomers in excellent yield, Scheme 3. Protection of the carbonyl group in $\mathbf{1 0}$ as the ethylene ketal, eliminative dehalogenation with sodium naphthalenide and ketal deprotection furnished the cyclobutene compound $\mathbf{1 1}$ as a single diastereomer. Catalytic hydrogenation of $\mathbf{1 1}$ led to the desired cis, anti, cis-tricyclic ketone 6. ${ }^{10}$ It is worth noting that the photocyclisation $\mathbf{9} \rightarrow \mathbf{1 0}$ proceeded exclusively from the exo-face of the diquinane moiety to generate the requisite relative stereochemistry of $C_{1}, C_{2}$ in the tricyclic ketone 6 .
To disengage the 4- and 5-membered rings in 6, a two-step protocol involving Baeyer-Villiger (BV) oxidation and alkylative opening of the resulting lactone with MeLi was considered. To our surprise, we observed that the tricyclic ketone 6 was resistant towards BV-oxidation. Several attempts to effect $\mathrm{BV}$-oxidation in $\mathbf{6}$, under various conditions using the reagents like $m$-CPBA, $30 \% \mathrm{H}_{2} \mathrm{O}_{2}$ in combination with $\mathrm{AcOH}$ or trifluoroacetic acid or trifluoroacetic anhydride showed either no reaction or very little conversion. However, the use of anhydrous trifluoroperacetic acid (generated from urea-hydrogen peroxide adduct and trifluoroacetic anhydride in dry $\mathrm{CH}_{2} \mathrm{Cl}_{2}$ at $\left.0-5^{\circ} \mathrm{C}\right)^{11}$ under high concentrations, gave, after 4-5 days, a 1:2 mixture of the regioisomeric lactones $\mathbf{1 2}$ and $\mathbf{1 3}$ in $82 \%$ yield, Scheme 4. Structures of regioisomeric lactones $\mathbf{1 2}$ and 13 were established on the basis of the ${ }^{1} \mathrm{H}-{ }^{1} \mathrm{H}$ TOCSY experiments. In the TOCSY of the major lactone 13, the $\mathrm{H}_{6}$ proton which is in alpha position to the carbonyl group had five connectivities due to one- $\mathrm{H}_{2}$, two- $\mathrm{H}_{3}$ and two- $\mathrm{H}_{5}$ protons but in the case of lactone $\mathbf{1 2}$, the $\mathrm{H}_{8}$ proton which is alpha to the carbonyl had less than five connectivities. While we were able to carry out the desired BV-oxidation of $\mathbf{6}$, the required regioisomeric lactone $\mathbf{1 2}$ was the minor product. Experimental manipulations to alter the ratio of regioisomeric lactones $\mathbf{1 2}$ and $\mathbf{1 3}$ were to no avail and consequently we decided to proceed further with the minor lactone 12. It is interesting to note that during the

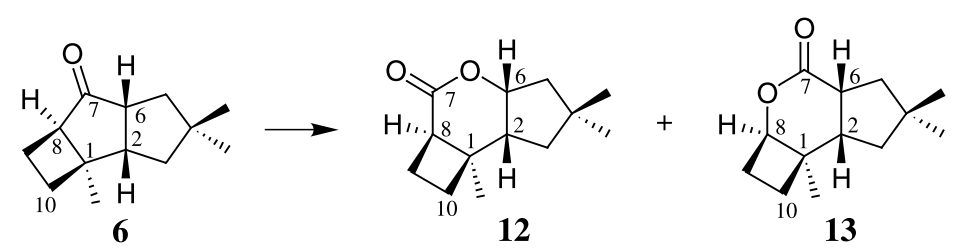

Scheme 4. Reagents and conditions: trifluoroperacetic acid, $\mathrm{Na}_{2} \mathrm{HPO}_{4}, \mathrm{CH}_{2} \mathrm{Cl}_{2}, 0-5^{\circ} \mathrm{C}, 4$ days, $82 \%(\mathbf{1 2 : 1 3}=1: 2)$. 


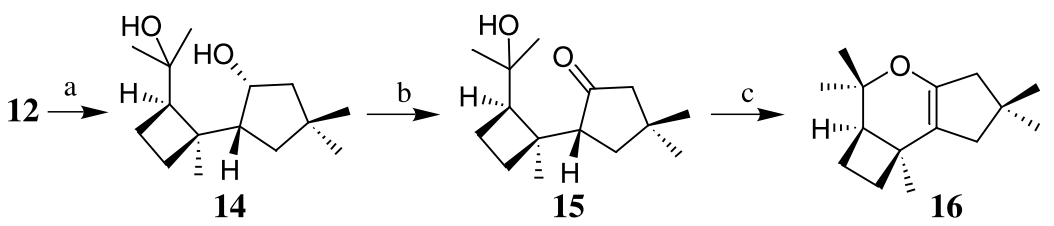

Scheme 5. Reagents and conditions: (a) $\mathrm{MeLi}, \mathrm{Et}_{2} \mathrm{O}, \mathrm{rt}, 4 \mathrm{~h}, 80 \%$; (b) TPAP, $\mathrm{NMO}, \mathrm{CH}_{2} \mathrm{Cl}_{2}, \mathrm{rt}, 45 \mathrm{~min}, 88 \%$; (c) $\mathrm{SOCl} 2, \mathrm{py}, 0^{\circ} \mathrm{C}$ or $\mathrm{POCl}{ }_{3}, \mathrm{py}, 0^{\circ} \mathrm{C}$ or $\mathrm{MsCl}$, DMAP, $\mathrm{CH}_{2} \mathrm{Cl}_{2}, \mathrm{rt}, 65-90 \%$.

$\mathrm{BV}$-oxidation of $\mathbf{6}$, there was preferential migration of the cyclobutane $\left(\mathrm{C}_{8}\right)$ carbon over the cyclopentane carbon $\left(\mathrm{C}_{6}\right)$, Scheme 4.

The minor lactone $\mathbf{1 2}$ was further elaborated towards the pre-target 7. Reaction of $\mathbf{1 2}$ with excess of MeLi furnished the desired ring opened dihydroxy compound 14 which had in place all the 15 carbon atoms present in the natural product 2. Catalytic TPAP oxidation ${ }^{12}$ of $\mathbf{1 4}$ furnished the hydroxy-ketone 15, Scheme 5. The IR spectrum of $\mathbf{1 5}$, derived from the minor lactone, showed the presence of a cyclopentanone moiety and reaffirmed our structural assignments of the lactones 12 and 13. Having obtained the hydroxy-ketone $\mathbf{1 5}$, the stage was now set for the key dehydration reaction to furnish the desired isopropylidenecyclobutane compound 7 . However, all the attempts towards this dehydration of $\mathbf{1 5}$, under various conditions led only to the formation of the undesired enol ether $\mathbf{1 6}$ in $70-90 \%$ yield, Scheme 5.

It was realised that the proximity of the ketone and the hydroxy group in $\mathbf{1 5}$ allowed the formation of $\mathbf{1 6}$. Hence, the ketone functionality needed to be modified. For this purpose, the secondary hydroxyl group in $\mathbf{1 4}$ was masked as the monoacetate 17 and its further exposure to $\mathrm{SOCl}_{2}$-py, under carefully controlled conditions, led to smooth dehydration and the desired tetrasubstituted isopropylidene cyclobutane compound $\mathbf{1 8}$ along with the minor disubstituted isomer 19 were obtained, Scheme 6. Both 18 and 19 were readily separated and their structures were deduced from spectral analyses. The olefin 18, corresponding to the pre-target 7 (Scheme 2) has the full 15-carbon content and the key structural features present in the sesquiterpenic natural products fomannosin $\mathbf{1}$ and illudosin 2. Further elaboration of $\mathbf{1 8}$ to the targeted natural product $\mathbf{2}$ required allylic oxidations and preliminary studies have indicated that the isopropylidene methyl group in it can be oxidised to an aldehyde group (cf. 2) with $\mathrm{SeO}_{2}$ under controlled conditions, setting the stage for accomplishing a synthesis of the natural product.

In summary, we have outlined a stereoselective synthesis of the carbocyclic framework $\mathbf{1 8}$ present in the sesquiterpene natural product illudosin $\mathbf{2}$, from a readily available diquinane precursor 5 .

\section{Experimental}

\subsection{General}

For a general write-up see Ref. 13.

1.1.1. (3a $S^{*}, 6 \mathrm{a} S$ *)-5,5-Dimethyl-1,3a,4,5,6,6a-hexahydro1-pentalenone (8). To a solution of LHMDS (12.3 mmol, obtained from $3.9 \mathrm{ml}$ of HMDS and $7.7 \mathrm{ml}$ of $1.6 \mathrm{M}^{n} \mathrm{BuLi}$ in hexanes at $\left.-78^{\circ} \mathrm{C}\right)$ in dry THF $(5 \mathrm{ml})$ was added the ketone $5(1.0 \mathrm{~g}, 6.58 \mathrm{mmol})$ in dry THF $(5 \mathrm{ml})$ over a period of $3 \mathrm{~min}$ at $-78^{\circ} \mathrm{C}$ under $\mathrm{N}_{2}$. After $1 \mathrm{~h}$, the enolate was quenched with a solution of freshly distilled $\mathrm{TMSCl}(3.1 \mathrm{ml})$ in dry THF $(2 \mathrm{ml})$. After $2 \mathrm{~h}$, the reaction was quenched with brine $(2 \mathrm{ml})$ and extracted with ether $(20 \mathrm{ml})$. The organic phase was washed again with brine $(5 \mathrm{ml})$ and dried. Removal of solvent furnished the TMS-enol ether.

A solution of the above enol ether and $\mathrm{Pd}(\mathrm{OAc})_{2}(1.48 \mathrm{~g}$, $6.58 \mathrm{mmol})$ in dry $\mathrm{CH}_{3} \mathrm{CN}(10 \mathrm{ml})$ was stirred under $\mathrm{N}_{2}$ at $\mathrm{rt}$ for $4 \mathrm{~h}$. The reaction mixture was filtered through a pad of Florisil ${ }^{\circledR}$ using pentane. Removal of solvent furnished the crude product, which was charged on a silica gel column and elution with $2 \%$ ethyl acetate-pentane removed less polar impurities. Further elution with $6 \%$ ethyl acetatepentane furnished the bicyclic-enone $\mathbf{8}$ as a clear liquid (810 mg, 82\%). IR (neat) $\nu_{\max } 3074,3043,1708 \mathrm{~cm}^{-1} ;{ }^{1} \mathrm{H}$ NMR $\left(300 \mathrm{MHz}, \mathrm{CDCl}_{3}\right): \delta 7.61(\mathrm{dd}, J=4.8,1.8 \mathrm{~Hz}, 1 \mathrm{H}$, olefinic-H), $5.96(\mathrm{~d}, J=5.7 \mathrm{~Hz}, 1 \mathrm{H}$, olefinic-H), 3.50-3.41 (m, 1H), 2.92-2.84 (m, 1H), 1.84-1.71 (m, 2H), 1.43 (dd, $J=12.9,7.8 \mathrm{~Hz}, 1 \mathrm{H}), 1.21(\mathrm{dd}, J=12.6,7.5 \mathrm{~Hz}, 1 \mathrm{H}), 0.99$ (s, $3 \mathrm{H}), 0.97(\mathrm{~s}, 3 \mathrm{H}) ;{ }^{13} \mathrm{C} \mathrm{NMR}\left(75 \mathrm{MHz}, \mathrm{CDCl}_{3}\right): \delta 213.4$, 167.8, 131.7, 50.2, 47.5, 43.9, 43.6, 42.0, 28.6, 28.0; EIMS $(20 \mathrm{eV}) \mathrm{m} / \mathrm{z} 150\left(\mathrm{M}^{+}\right)$. A satisfactory elemental analysis for this compound could not be obtained.

1.1.2. $(3 \mathrm{a} S *, 6 \mathrm{a} R *)-3,5,5$-Trimethyl-1,3a,4,5,6,6a-hexahydro-1-pentalenone (9). To a solution of enone $\mathbf{8}$ $(0.56 \mathrm{~g}, 3.73 \mathrm{mmol})$ in dry ether $(10 \mathrm{ml})$ at $0^{\circ} \mathrm{C}$ was added

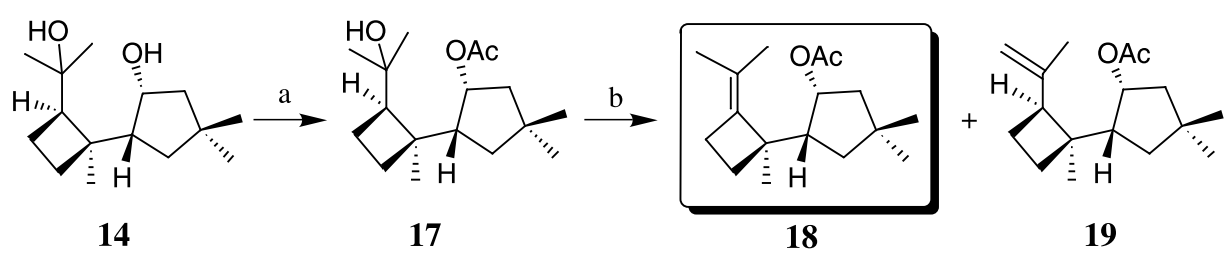

Scheme 6. Reagents and conditions: (a) $\mathrm{Ac}_{2} \mathrm{O}, \mathrm{DMAP}, \mathrm{CH}_{2} \mathrm{Cl}_{2}, \mathrm{rt}, 10 \mathrm{~h}, 86 \%$; (b) $\mathrm{SOCl}_{2}, \mathrm{py}, 0^{\circ} \mathrm{C}, 30 \mathrm{~min}, 40 \%(\mathbf{1 8}: 19=70: 30)$. 
MeLi (4.9 mmol, $3.8 \mathrm{ml}$ of $1.3 \mathrm{M}$ solution in ether) and stirred at $0^{\circ} \mathrm{C}$ under $\mathrm{N}_{2}$. After $15 \mathrm{~min}$, the reaction was quenched with water $(5 \mathrm{ml})$, diluted with ether $(25 \mathrm{ml})$, washed with brine $(10 \mathrm{ml})$ and dried. Removal of solvent furnished a mixture of alcohols as a clear liquid $(570 \mathrm{mg}$, $92 \%$ ), which was used as such for the next step.

The mixture of above alcohols $(0.48 \mathrm{~g}, 2.89 \mathrm{mmol})$ and PCC $(1.01 \mathrm{~g}, 4.7 \mathrm{mmol})$ in dry $\mathrm{CH}_{2} \mathrm{Cl}_{2}(20 \mathrm{ml})$ was stirred at $5-10^{\circ} \mathrm{C}$ for $10 \mathrm{~min}$ and allowed to attain rt. After $2 \mathrm{~h}$, the reaction mixture was poured into dry ether $(20 \mathrm{ml})$ and filtered through a florisil ${ }^{\circledR}$ pad. Removal of solvent furnished the crude product, which was charged on a silica gel column. Elution with $10 \%$ ethyl acetate-pentane furnished the enone 9 as a clear liquid (402 mg, 85\%), which was bulb to bulb distilled $\left(130-140^{\circ} \mathrm{C}\right.$ at 1.5 Torr, bath). IR (neat) $\nu_{\max } 3066,1700,1618 \mathrm{~cm}^{-1} ;{ }^{1} \mathrm{H}$ NMR $\left(300 \mathrm{MHz}, \mathrm{CDCl}_{3}\right): \delta 5.71(\mathrm{~s}, 1 \mathrm{H}$, olefinic-H), 3.27 (q, $J=$ $8.7 \mathrm{~Hz}, 1 \mathrm{H}), 3.01-2.93(\mathrm{~m}, 1 \mathrm{H}), 2.07$ (s, 3H, olefinic-Me), $1.85-1.71(\mathrm{~m}, 2 \mathrm{H}), 1.43(\mathrm{dd}, J=12.9,7.5 \mathrm{~Hz}, 1 \mathrm{H}), 1.21(\mathrm{dd}$, $J=12.6,7.8 \mathrm{~Hz}, 1 \mathrm{H}), 1.00(\mathrm{~s}, 6 \mathrm{H}) ;{ }^{13} \mathrm{C}$ NMR $(75 \mathrm{MHz}$, $\left.\mathrm{CDCl}_{3}\right): \delta 212.6,181.3,128.3,51.9,50.7,43.7,43.4,41.8$, 28.6, 27.8, 17.9; EIMS (20 eV) $\mathrm{m} / \mathrm{z} 164\left(\mathrm{M}^{+}\right)$.

1.1.3. Photocycloaddition of 9 with trans 1,2-dichloroethylene. A solution of $9(250 \mathrm{mg}, 1.52 \mathrm{mmol})$ and trans1,2-dichloroethylene $(5 \mathrm{ml})$ in dry cyclohexane $(5 \mathrm{ml})$ was degassed with Argon and irradiated with a $450 \mathrm{~W}$ medium pressure Hanovia mercury vapor lamp using pyrex filter for $4.5 \mathrm{~h}$. The solvent was removed and the crude material was charged on a silica gel column. Elution with $1 \%$ ethyl acetate-hexane removed the less polar impurities. Further elution with $7 \%$ ethyl acetate-hexane furnished 1,2-dichlorocyclobutane isomers 10a (223 mg, 56\%), 10b (37 mg, 9\%) and 10c (112 mg, 28\%) as clear liquids. The relative stereochemistry of the chlorine substituents can be inferred from the vicinal couplings between the protons of the cyclobutane ring as typically $J_{v i c}($ cis $)>J_{v i c}($ trans $)$ in 1,2-disubstituted cyclobutanes. ${ }^{14}$ 10a: IR (neat) $\nu_{\max } 1736 \mathrm{~cm}^{-1}$; ${ }^{1} \mathrm{H}$ NMR $\left(300 \mathrm{MHz}, \mathrm{CDCl}_{3}\right): \delta 4.46(\mathrm{dd}, J=5.4,1.5 \mathrm{~Hz}$, $1 \mathrm{H}), 4.09$ (dd, $J=5.4,3.9 \mathrm{~Hz}, 1 \mathrm{H}), 3.24-3.08(\mathrm{~m}, 2 \mathrm{H}), 2.72$ $(\mathrm{d}, J=3.9 \mathrm{~Hz}, 1 \mathrm{H}), 1.75(\mathrm{~d}, J=6.9 \mathrm{~Hz}, 2 \mathrm{H}), 1.48(\mathrm{dd}, J=$ 12.3, $6.6 \mathrm{~Hz}, 1 \mathrm{H}), 1.38$ (s, 3H), 1.08-0.97 (m, 1H), 1.05 (s, $3 \mathrm{H}), 1.02(\mathrm{~s}, 3 \mathrm{H}) ;{ }^{13} \mathrm{C}$ NMR $\left(75 \mathrm{MHz}, \mathrm{CDCl}_{3}\right): \delta 216.2$, $70.2,60.5,57.2,53.0,44.8,44.2,43.3,41.1,40.1,29.4$, 28.2, 23.8; 10b: IR (neat) $\nu_{\max } 1738 \mathrm{~cm}^{-1} ;{ }^{1} \mathrm{H}$ NMR $\left(300 \mathrm{MHz}, \mathrm{CDCl}_{3}\right): \delta 4.49(\mathrm{dd}, J=10.2,7.8 \mathrm{~Hz}, 1 \mathrm{H}), 4.34$ $(\mathrm{dd}, J=7.8,0.9 \mathrm{~Hz}, 1 \mathrm{H}), 3.08-3.00(\mathrm{~m}, 1 \mathrm{H}), 2.91(\mathrm{~d}, J=$ $10.2 \mathrm{~Hz}, 1 \mathrm{H}), 2.82-2.73(\mathrm{~m}, 1 \mathrm{H}), 1.89-1.74(\mathrm{~m}, 2 \mathrm{H}), 1.52$ (dd, $J=12.6,6.6 \mathrm{~Hz}, 1 \mathrm{H}), 1.28(\mathrm{~s}, 3 \mathrm{H}), 1.25-1.17(\mathrm{~m}, 1 \mathrm{H})$, $1.05(\mathrm{~s}, 3 \mathrm{H}), 0.98(\mathrm{~s}, 3 \mathrm{H}) ;{ }^{13} \mathrm{C}$ NMR $\left(75 \mathrm{MHz}, \mathrm{CDCl}_{3}\right): \delta$ 216.9, 67.4, 55.6, 54.49, 54.46, 50.8, 47.3, 43.6, 42.3, 40.4, 29.5, 28.5, 16.6; 10c: IR (neat) $\nu_{\max } 1737 \mathrm{~cm}^{-1} ;{ }^{1} \mathrm{H}$ NMR $\left(300 \mathrm{MHz}, \mathrm{CDCl}_{3}\right): \delta 4.61(\mathrm{dd}, J=6.6,1.5 \mathrm{~Hz}, 1 \mathrm{H}), 4.41$ $(\mathrm{dd}, J=6.6,0.9 \mathrm{~Hz}, 1 \mathrm{H}), 3.12-3.04(\mathrm{~m}, 1 \mathrm{H}), 2.79-2.71(\mathrm{~m}$, $2 \mathrm{H}), 1.91-1.82(\mathrm{~m}, 2 \mathrm{H}), 1.65-1.51(\mathrm{~m}, 2 \mathrm{H}), 1.44(\mathrm{~s}, 3 \mathrm{H})$, $1.04(\mathrm{~s}, 3 \mathrm{H}), 0.96(\mathrm{~s}, 3 \mathrm{H}) ;{ }^{13} \mathrm{C} \mathrm{NMR}\left(75 \mathrm{MHz}, \mathrm{CDCl}_{3}\right): \delta$ 219.1, 61.6, 57.9, 57.5, 53.0, 50.3, 49.5, 43.5, 43.0, 40.3, 29.1, 27.8, 17.9.

1.1.4. $\left(2 \mathrm{a} R^{*}, 2 \mathrm{~b} S *, 5 \mathrm{a} R^{*}, 6 \mathrm{a} R^{*}\right)-2 \mathrm{a}, 4,4-T$ rimethyl-2a, $2 \mathrm{~b}, 3$, 4,5,5a,6,6a-octahydrocyclobuta $[a]$-pentalen-6-one (11). The above mixture of tricyclic ketones $\mathbf{1 0 a}-\mathbf{c}(300 \mathrm{mg}$,
$1.15 \mathrm{mmol}$ ) were subjected to carbonyl protection using excess ethylene glycol $(1 \mathrm{ml})$ and PTSA $(10 \mathrm{mg})$ in dry benzene $(20 \mathrm{ml})$ using a Dean-Stark water separator for $24 \mathrm{~h}$. The reaction was washed with aq. sodium bicarbonate ( $5 \mathrm{ml})$ and dried. The solvent was removed and the crude material was charged on a silica gel column. Elution with $10 \%$ ethyl acetate-hexane furnished a mixture of ketals (350 mg, 80\%), which were used as such for the next step.

To a solution of above ketals $(350 \mathrm{mg}, 0.92 \mathrm{mmol})$ in dry DME $(10 \mathrm{ml})$ at $\mathrm{rt}$, sodium naphthalenide reagent (prepared from $0.313 \mathrm{~g}, 13.6 \mathrm{mmol}$ of sodium and $3.84 \mathrm{~g}, 30 \mathrm{mmol}$ of naphthalene in DME, $25 \mathrm{ml}$ at $\mathrm{rt}$ for $12 \mathrm{~h}$ ) ${ }^{15}$ was added until the deep bluish-green colour persisted. After $30 \mathrm{~min}$ the reaction was quenched with dry methanol $(1 \mathrm{ml})$ and saturated $\mathrm{NH}_{4} \mathrm{Cl}$ solution $(5 \mathrm{ml})$ and extracted with ether (30 ml). The organic phase was washed with brine $(10 \mathrm{ml})$ and dried. Removal of solvent gave a crude product, which was charged on a silica gel column, elution with $1 \%$ ethyl acetate-hexane removed naphthalene and less polar impurities. Further elution with 5\% ethyl acetate-hexane furnished the cyclobutene ketal as a colorless liquid (204 mg, 95\%), which was stirred with Amberlyst-15 resin in acetone for $10 \mathrm{~h}$ at $\mathrm{rt}$. The reaction mixture was filtered and the solvent was evaporated. The crude product was charged on a silica gel column, elution with $7 \%$ ethyl acetate-hexane furnished the unsaturated cis, anti, cistricyclic ketone 11 as a clear liquid (152 mg, 87\%), which was bulb to bulb distilled $\left(130-140^{\circ} \mathrm{C}\right.$ at 1.5 Torr, bath). IR (neat) $\nu_{\max } 3046,1734 \mathrm{~cm}^{-1} ;{ }^{1} \mathrm{H}$ NMR $\left(300 \mathrm{MHz}, \mathrm{CDCl}_{3}\right)$ : $\delta 6.45(\mathrm{dd}, J=2.4,0.6 \mathrm{~Hz}, 1 \mathrm{H}), 6.12(\mathrm{dd}, J=2.7,1.2 \mathrm{~Hz}$, $1 \mathrm{H}), 3.32-3.24(\mathrm{~m}, 1 \mathrm{H}), 2.94(\mathrm{~s}, 1 \mathrm{H}), 2.72-2.63(\mathrm{~m}, 1 \mathrm{H})$, $1.76-1.68(\mathrm{~m}, 2 \mathrm{H}), 1.45(\mathrm{dd}, J=12.3,6.0 \mathrm{~Hz}, 1 \mathrm{H}), 1.28(\mathrm{~s}$, $3 \mathrm{H}), 1.04-0.92(\mathrm{~m}, 1 \mathrm{H}), 1.04(\mathrm{~s}, 3 \mathrm{H}), 0.96(\mathrm{~s}, 3 \mathrm{H}) ;{ }^{13} \mathrm{C}$ NMR (75 MHz, $\left.\mathrm{CDCl}_{3}\right): \delta 220.0,149.3,133.9,60.8,51.7$, 51.0, 44.9, 43.5, 41.2, 40.2, 29.8, 28.7, 19.0; EIMS (20 eV) $\mathrm{m} / z 190\left(\mathrm{M}^{+}\right)$. Anal. calcd for $\mathrm{C}_{13} \mathrm{H}_{18} \mathrm{O}$ : C, 82.06; H, 9.53. Found. C, 82.27; H, 9.71.

1.1.5. $(2 \mathrm{a} R *, 2 \mathrm{bS} *, 5 \mathrm{a} R *, 6 \mathrm{a} R *)-2 \mathrm{a}, 4,4-T r i m e t h y l p e r h y d r o-$ cyclobuta[a]pentalen-6-one (6). Tricyclic olefin 11 $(130 \mathrm{mg}, 0.68 \mathrm{mmol})$ was stirred under an atmosphere of hydrogen over $\mathrm{PtO}_{2}(1 \mathrm{mg})$ catalyst in ethyl acetate $(5 \mathrm{ml})$ for $2 \mathrm{~h}$. The reaction mixture was diluted with hexane $(6 \mathrm{ml})$ and filtered through a small silica gel pad. Removal of solvent furnished the tricyclic ketone $\mathbf{6}$ as a clear liquid (126 mg, 97\%). IR (neat) $\nu_{\max } 1732 \mathrm{~cm}^{-1}$; ${ }^{1} \mathrm{H}$ NMR (300 MHz, $\left.\mathrm{CDCl}_{3}\right): \delta 3.20-3.12(\mathrm{~m}, 1 \mathrm{H}), 2.59-2.37$ (series of $\mathrm{m}, 2 \mathrm{H}), 2.14-1.69$ (series of $\mathrm{m}, 4 \mathrm{H}), 1.44-1.37(\mathrm{~m}, 1 \mathrm{H})$, $1.28-1.21(\mathrm{~m}, 1 \mathrm{H}), 1.22(\mathrm{~s}, 3 \mathrm{H}), 1.06-0.98(\mathrm{~m}, 1 \mathrm{H}), 1.02$ $(\mathrm{s}, 3 \mathrm{H}), 0.96(\mathrm{~s}, 3 \mathrm{H}), 0.84(\mathrm{t}, J=12.3 \mathrm{~Hz}, 1 \mathrm{H}) ;{ }^{13} \mathrm{C} \mathrm{NMR}$ $\left(75 \mathrm{MHz}, \mathrm{CDCl}_{3}\right): \delta$ 226.1, 53.4, 52.1, 49.9, 43.4, 42.4, 42.1, 40.0, 32.4, 29.7, 28.7, 21.9, 18.7; EIMS (20 eV) $\mathrm{m} / z$ $192\left(\mathrm{M}^{+}\right)$.

1.1.6. Baeyer-Villiger oxidation of (6). A mixture of ketone 6 (200 mg, $1.04 \mathrm{mmol}), \mathrm{Na}_{2} \mathrm{HPO}_{4}(300 \mathrm{mg})$ and anhydrous trifluoroperacetic acid (prepared from $2 \mathrm{~g}$ of urea-hydrogen peroxide adduct and $2 \mathrm{ml}$ of trifluoroacetic anhydride in $5 \mathrm{ml}$ of dry $\mathrm{CH}_{2} \mathrm{Cl}_{2}$ at $\left.0-5^{\circ} \mathrm{C}\right)^{11}$ in dry $\mathrm{CH}_{2} \mathrm{Cl}_{2}$ $(2 \mathrm{ml})$ was stirred at $0-5^{\circ} \mathrm{C}$ for 4 days. The reaction mixture was washed with brine $(5 \mathrm{ml})$, dried and the solvent was evaporated. The GLC analysis of the crude product showed 
the presence of a 2:1 mixture of products, indicating the formation of two regioisomeric lactones. The mixture of lactones was charged on a silica gel column and elution with 7\% ethyl acetate-hexane furnished the major lactone $\mathbf{1 3}$ as a viscous liquid (117 mg, 54\%). The regiochemistry of lactone 13 followed from its ${ }^{1} \mathrm{H},{ }^{13} \mathrm{C}$ and TOCSY spectra. IR (neat) $\nu_{\max } 1736 \mathrm{~cm}^{-1} ;{ }^{1} \mathrm{H} \mathrm{NMR}\left(300 \mathrm{MHz}, \mathrm{CDCl}_{3}\right): \delta 4.52$ (dd, $J=7.8,4.5 \mathrm{~Hz}, 1 \mathrm{H}, \mathrm{H}-3), 3.00-2.95(\mathrm{~m}, 1 \mathrm{H}, \mathrm{H}-11)$, $2.51-2.40(\mathrm{~m}, 1 \mathrm{H}), 2.40(\mathrm{~d}, J=13.5 \mathrm{~Hz}, 1 \mathrm{H}), 2.23-2.15(\mathrm{~m}$, $1 \mathrm{H}), 2.01-1.86(\mathrm{~m}, 2 \mathrm{H}), 1.73-1.61(\mathrm{~m}, 2 \mathrm{H}), 1.54$ (dd, $J=$ $12.9,6.3 \mathrm{~Hz}, 1 \mathrm{H}), 1.18(\mathrm{~s}, 3 \mathrm{H}), 1.11(\mathrm{~d}, J=13.2 \mathrm{~Hz}, 1 \mathrm{H})$, $1.03(\mathrm{~s}, 3 \mathrm{H}), 0.99$ (s, 3H); ${ }^{13} \mathrm{C}$ NMR $\left(75 \mathrm{MHz} \mathrm{CDCl}_{3}\right)$ : $\delta$ 174.0, 80.6, 46.8, 43.9, 43.5, 42.9, 38.4, 36.6, 31.6, 31.4, 29.2, 26.1, 25.3; EIMS (20 eV) m/z $208\left(\mathrm{M}^{+}\right)$. Anal. calcd for $\mathrm{C}_{13} \mathrm{H}_{20} \mathrm{O}_{2}$ : C, 74.96; H, 9.68. Found: C, 75.01; H, 9.81 .

Continued elution with $10 \%$ ethyl acetate-hexane furnished the minor lactone $\mathbf{1 2}$ as a clear liquid (58 mg, 27\%). The regiochemistry of lactone $\mathbf{1 2}$ followed from its ${ }^{1} \mathrm{H},{ }^{13} \mathrm{C}$ and TOCSY spectra. IR (neat) $\nu_{\max } 1729 \mathrm{~cm}^{-1} ;{ }^{1} \mathrm{H}$ NMR $\left(300 \mathrm{MHz}, \mathrm{CDCl}_{3}\right): \delta 5.05-5.03(\mathrm{~m}, 1 \mathrm{H}, \mathrm{H}-11), 2.75(\mathrm{dd}$, $J=10.6,5.0 \mathrm{~Hz}, 1 \mathrm{H}, \mathrm{H}-3), 2.51-2.40(\mathrm{~m}, 1 \mathrm{H}), 2.05-1.91$ $(\mathrm{m}, 5 \mathrm{H}), 1.81-1.75(\mathrm{~m}, 1 \mathrm{H}), 1.51(\mathrm{dd}, J=13.2,7.0 \mathrm{~Hz}, 1 \mathrm{H})$, 1.24 (d, $J=13.2 \mathrm{~Hz}, 1 \mathrm{H}), 1.16$ (s, 3H), 1.14 (s, 3H), 1.08 (s, $3 \mathrm{H}) ;{ }^{13} \mathrm{C} \mathrm{NMR}\left(75 \mathrm{MHz}, \mathrm{CDCl}_{3}\right): \delta 174.9,84.2,48.1,47.0$, 40.1, 39.8, 37.1, 36.6, 32.0, 31.6 (2C), 26.7, 18.7; EIMS $(20 \mathrm{eV}) \mathrm{m} / \mathrm{z}, 208\left(\mathrm{M}^{+}\right)$. Anal. calcd for $\mathrm{C}_{13} \mathrm{H}_{20} \mathrm{O}_{2}$ : C, 74.96; H, 9.68. Found: C, 75.07; H, 9.88.

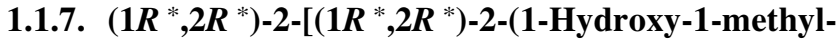
ethyl)-1-methylcyclobutyl]-4,4-dimethylcyclopentan-1ol (14). To a solution of 12 (40 mg, $0.19 \mathrm{mmol})$ in dry ether ( $5 \mathrm{ml}$ ) excess $\mathrm{MeLi}$ ( $2 \mathrm{M}$ solution in ether, $2 \mathrm{ml}$ ) was added and stirred at rt. After $4 \mathrm{~h}$, the reaction was quenched with water $(3 \mathrm{ml})$, extracted with ether $(10 \mathrm{ml})$, washed and dried. Evaporation of solvent furnished a white solid, which was charged on a silica gel column. Elution with $20 \%$ ethyl acetate-hexane furnished the diol $\mathbf{1 4}$ as a white solid (36 mg, 80\%). Mp 106-108 ${ }^{\circ} \mathrm{C}$. IR (neat) $\nu_{\max } 1720 \mathrm{~cm}^{-1}$; ${ }^{1} \mathrm{H}$ NMR $\left(300 \mathrm{MHz}, \mathrm{CDCl}_{3}\right): \delta 4.54-4.47(\mathrm{~m}, 1 \mathrm{H}, \mathrm{H}-11)$, $2.95-2.75(\mathrm{br}, 1 \mathrm{H}), 2.71-2.62(\mathrm{~m}, 1 \mathrm{H}), 2.20(\mathrm{t}, J=8.7 \mathrm{~Hz}$, $1 \mathrm{H}), 1.96-1.44(\mathrm{~m}, 9 \mathrm{H}), 1.38(\mathrm{~s}, 3 \mathrm{H}), 1.34(\mathrm{~s}, 3 \mathrm{H}), 1.18(\mathrm{~s}$, $3 \mathrm{H}), 1.10(\mathrm{~s}, 3 \mathrm{H}), 0.97$ (s, 3H); ${ }^{13} \mathrm{C}$ NMR (75 MHz, $\left.\mathrm{CDCl}_{3}\right)$ : $\delta$ 75.6, 72.9, 56.6, 50.2, 45.3, 44.3, 42.1, 35.3, 32.2, 30.7, 30.6, 29.4, 28.1, 26.7, 19.7; EIMS $(20 \mathrm{eV}) \mathrm{m} / \mathrm{z} 204$ $\left(\mathrm{M}^{+}-2 \mathrm{H}_{2} \mathrm{O}\right)$. Anal. calcd for $\mathrm{C}_{15} \mathrm{H}_{28} \mathrm{O}_{2}: \mathrm{C}, 74.95 ; \mathrm{H}$, 11.74. Found: C, 74.88; H, 11.70 .

1.1.8. $\left(2 R^{*}\right)-2-\left[\left(1 S^{*}, 2 R^{*}\right)-2-(1-H y d r o x y-1-m e t h y l e t h y l)-\right.$ 1-methylcyclobutyl]-4,4-dimethyl-cyclopentan-1-one (15). A mixture of diol 14 (20 mg, $0.083 \mathrm{mmol})$, NMMO (14 $\mathrm{mg}, 0.12 \mathrm{mmol})$ and $n$-tetrabutyl-ammonium perruthenate (TPAP, $1 \mathrm{mg})^{11}$ in dry $\mathrm{CH}_{2} \mathrm{Cl}_{2}(5 \mathrm{ml})$ was stirred at $\mathrm{rt}$ for $45 \mathrm{~min}$. The reaction mixture was washed with brine and dried over anhydrous sodium sulfate. Evaporation of solvent furnished the crude keto alcohol, which was purified by a small silica gel pad using $10 \%$ ethyl acetate-hexane as the eluent, to furnish $\mathbf{1 5}$ as a clear liquid (17 $\mathrm{mg}, 88 \%)$. IR (neat) $\nu_{\max } 3450,1722 \mathrm{~cm}^{-1}$; ${ }^{1} \mathrm{H} \mathrm{NMR}\left(300 \mathrm{MHz}, \mathrm{CDCl}_{3}\right)$ : $\delta 4.88(\mathrm{~s}, 1 \mathrm{H}, \mathrm{OH}), 3.49(\mathrm{t}, J=10.2 \mathrm{~Hz}, 1 \mathrm{H}), 2.23-1.44(\mathrm{~m}$, 9H), $1.20(\mathrm{~s}, 6 \mathrm{H}), 1.15(\mathrm{~s}, 3 \mathrm{H}), 1.08(\mathrm{~s}, 3 \mathrm{H}), 1.03(\mathrm{~s}, 3 \mathrm{H}) ;{ }^{13} \mathrm{C}$ NMR (75 MHz, $\left.\mathrm{CDCl}_{3}\right): \delta 225.6,71.1,56.9,55.6,49.8$,
$45.4,41.5,33.2,31.2,30.0,29.5,27.7,26.1,24.6,19.5$; EIMS $(20 \mathrm{eV}) \mathrm{m} / \mathrm{z} 220\left(\mathbf{M}^{+}-18\right)$. HRMS calcd for $\mathrm{C}_{15} \mathrm{H}_{26} \mathrm{O}_{2}-\mathrm{H}_{2} \mathrm{O} 220.1827$, found 220.1826.

1.1.9. $\left(2 \mathrm{a} R R^{*}, 7 \mathrm{~b} S^{*}\right)-3,3,6,6,7 \mathrm{~b}-$ Pentamethyl-1,2,2a, $3,5,6,7,7 b-o c t a h y d r o c y c l o b u t a[d]$-cyclopenta $[b]$ pyran (16). To the keto alcohol $15(5 \mathrm{mg}, 0.021 \mathrm{mmol})$ in dry pyridine $(0.2 \mathrm{ml})$ at $0^{\circ} \mathrm{C}$, was added freshly distilled $\mathrm{SOCl}_{2}$ $(0.05 \mathrm{ml})$ and stirred under $\mathrm{N}_{2}$. After $2 \mathrm{~h}$, the reaction mixture was diluted with $n$-pentane, washed with brine $(5 \mathrm{ml})$ and dried. Solvent was evaporated and the crude material was charged on a silica gel column. Elution with 2\% ethyl acetate-hexane furnished $\mathbf{1 6}$ as a clear liquid (3 mg, 65\%). IR (neat) $\nu_{\max } 1684 \mathrm{~cm}^{-1} ;{ }^{1} \mathrm{H} \quad \mathrm{NMR}$ $\left(300 \mathrm{MHz}, \mathrm{CDCl}_{3}\right): \delta 2.15-1.58$ (series of $\mathrm{m}, 9 \mathrm{H}$ ), 1.13 (s, 3H), $1.12(\mathrm{~s}, 6 \mathrm{H}), 1.10(\mathrm{~s}, 3 \mathrm{H}), 1.09(\mathrm{~s}, 3 \mathrm{H}) ;{ }^{13} \mathrm{C}$ NMR $\left(75 \mathrm{MHz}, \mathrm{CDCl}_{3}\right): \delta 145.9,109.9,75.2,49.7,46.9,42.6$, $36.9,34.7,30.5,30.3,30.1,25.7,25.2$, 24.0, 18.4; EIMS $(20 \mathrm{eV}) \mathrm{m} / \mathrm{z} 220\left(\mathrm{M}^{+}\right)$.

1.1.10. $\left(1 R^{*}, 2 R^{*}\right)-2-\left[\left(1 R^{*}, 2 R^{*}\right)-2-(1-H y d r o x y-1-m e t h y l-\right.$ ethyl)-1-methylcyclobutyl]-4,4-dimethylcyclopentyl acetate (17). A mixture of diol 14 (18 $\mathrm{mg}, 0.075 \mathrm{mmol})$, acetic anhydride $(1 \mathrm{ml})$ and DMAP $(2 \mathrm{mg})$ in dry $\mathrm{CH}_{2} \mathrm{Cl}_{2}$ $(5 \mathrm{ml})$ was stirred under $\mathrm{N}_{2}$ for $10 \mathrm{~h}$ at $\mathrm{rt}$. The solvent was removed under reduced pressure and the crude material was charged on a silica gel column. Elution with $20 \%$ ethyl acetate-hexane furnished the monoacetate $\mathbf{1 7}$ as a viscous liquid $(18 \mathrm{mg}, 86 \%)$. IR (neat) $\nu_{\max } 3503,1735 \mathrm{~cm}^{-1} ;{ }^{1} \mathrm{H}$ NMR $\left(300 \mathrm{MHz}, \mathrm{CDCl}_{3}\right): \delta 5.26(\mathrm{t}, J=4.2 \mathrm{~Hz}, 1 \mathrm{H}), 2.43-$ $2.35(\mathrm{~m}, 1 \mathrm{H}), 2.10-1.46(\mathrm{~m}, 10 \mathrm{H}), 1.99(\mathrm{~s}, 3 \mathrm{H}), 1.22$ (s, 3H), 1.17 (s, 3H), 1.11 (s, 3H), 1.10 (s, 3H), 1.04 (s, 3H); ${ }^{13} \mathrm{C}$ NMR $\left(75 \mathrm{MHz}, \mathrm{CDCl}_{3}\right): \delta 170.7,81.2,71.7,57.7$, $47.5,46.0,44.0,42.2,36.0,32.2,31.5,30.0,29.9$, 29.8, 28.4, 21.6, 19.2; EIMS (20 eV) $\mathrm{m} / \mathrm{z} 282\left(\mathrm{M}^{+}\right)$. HRMS calcd for $\mathrm{C}_{17} \mathrm{H}_{30} \mathrm{O}_{3}-\mathrm{CH}_{3} \mathrm{CO}_{2} \mathrm{H}-\mathrm{H}_{2} \mathrm{O} 204.1878$, found 204.1884.

1.1.11. $\left(1 R^{*}, 2 R^{*}\right)-4,4$-Dimethyl-2-[(1R*)-1-methyl-2-(1methylethylidene)cyclobutyl]-cyclopentyl acetate (18). To the alcohol $17(8 \mathrm{mg}, 0.028 \mathrm{mmol})$ in dry pyridine $(0.2 \mathrm{ml})$ at $0^{\circ} \mathrm{C}$, was added freshly distilled $\mathrm{SOCl}_{2}(0.05 \mathrm{ml})$ and stirred under $\mathrm{N}_{2}$. After $30 \mathrm{~min}$, the reaction mixture was diluted with $n$-pentane, washed with brine and dried.over anhydrous sodium sulfate. Solvent was evaporated and the crude material was charged on a $10 \% \mathrm{AgNO}_{3}$ impregnatedsilica gel column. Elution with $0.5 \%$ ethyl acetate-hexane furnished the tetrasubstituted olefin $\mathbf{1 8}$ as a clear liquid (3 mg, 40\%). IR (neat) $\nu_{\max } 1737,1450,1371,1245 \mathrm{~cm}^{-1}$; ${ }^{1} \mathrm{H}$ NMR $\left(300 \mathrm{MHz}, \mathrm{CDCl}_{3}\right): \delta 5.25(\mathrm{t}, J=4.8 \mathrm{~Hz}, 1 \mathrm{H})$, $2.50-1.98(\mathrm{~m}, 4 \mathrm{H}), 1.98(\mathrm{~s}, 3 \mathrm{H}), 1.87-1.74(\mathrm{~m}, 2 \mathrm{H}), 1.55$ (s, 3H), 1.55-1.44 (m, 3H), $1.44(\mathrm{~s}, 3 \mathrm{H}), 1.25(\mathrm{~s}, 3 \mathrm{H}), 1.12$ $(\mathrm{s}, 3 \mathrm{H}), 1.02(\mathrm{~s}, 3 \mathrm{H}) ;{ }^{13} \mathrm{C} \mathrm{NMR}\left(75 \mathrm{MHz}, \mathrm{CDCl}_{3}\right): \delta 170.6$, 139.3, 121.8, 78.3, 49.6, 48.7, 46.5, 41.9, 36.4, 31.8, 31.2, 26.5, 25.6, 24.8, 21.6, 19.4, 18.5; EIMS (20 eV) m/z 264 $\left(\mathrm{M}^{+}\right)$. HRMS calcd for $\mathrm{C}_{17} \mathrm{H}_{28} \mathrm{O}_{2}-\mathrm{CH}_{3} \mathrm{CO}_{2} \mathrm{H}$ 204.1878, found 204.1871. Continued elution led to olefin $19(1.4 \mathrm{mg}$, $19 \%$ ), as a clear liquid. IR (neat) $\nu_{\max } 3078,1737$, $1644 \mathrm{~cm}^{-1}$; ${ }^{1} \mathrm{H}$ NMR $\left(300 \mathrm{MHz}, \mathrm{CDCl}_{3}\right): \delta 5.16(\mathrm{t}, J=$ $4.5 \mathrm{~Hz}, 1 \mathrm{H}), 4.85(\mathrm{~s}, 1 \mathrm{H}), 4.66(\mathrm{~s}, 1 \mathrm{H}), 2.64(\mathrm{t}, J=9.0 \mathrm{~Hz}$, $1 \mathrm{H}), 2.14-1.44(\mathrm{~m}, 8 \mathrm{H}), 1.98(\mathrm{~s}, 3 \mathrm{H}), 1.70$ (s, 3H), 1.29$1.21(\mathrm{~m}, 1 \mathrm{H}) 1.22(\mathrm{~s}, 3 \mathrm{H}), 1.10(\mathrm{~s}, 3 \mathrm{H}), 0.99$ (s, 3H); EIMS $(20 \mathrm{eV}) \mathrm{m} / \mathrm{z} 264\left(\mathrm{M}^{+}\right)$. 


\section{Acknowledgements}

K. S. would like to thank UGC for the award of a research fellowship. We thank SIF at IISc in providing the high field NMR spectra.

\section{References}

1. (a) Kepler, J. A.; Wall, M. E.; Mason, J. E.; Basset, C.; McPhail, A. T.; Sim, G. A. J. Am. Chem. Soc. 1967, 89, 1260. (b) McPhail, A. T.; Sim, G. A. J. Chem. Soc., B 1968, 1104. (c) Nozoe, S.; Matsumoto, H.; Urano, S. Tetrahedron Lett. 1971, 3125.

2. (a) Arnone, A.; Cardillo, R.; Nasini, G.; Vajna de Pava, O. J. Chem. Soc., Perkin Trans. 1 1991, 1787. (b) Burgess, M. L.; Barrow, K. D. J. Chem. Soc., Perkin Trans. 1 1999, 2461. (c) McMorris, T. C.; Lira, R.; Gantzel, P. K.; Kelner, M. J.; Dawe, R. J. Nat. Prod. 2000, 63, 1557.

3. Basset, C.; Sherwood, R. T.; Kepler, J. A.; Hamilton, P. B. Phytopathology 1967, 57, 1046.

4. Semmelhack, M. F.; Tomoda, S.; Nagaoka, H.; Boettger, S. D.; Hurst, K. M. J. Am. Chem. Soc. 1982, 104, 747.

5. (a) Miyano, K.; Ohfune, Y.; Azuma, S.; Matsumoto, T.
Tetrahedron Lett. 1974, 1545. (b) Kosugi, H.; Uda, H. Bull. Chem. Soc. Jpn 1980, 53, 160.

6. (b) Mehta, G.; Sreenivas, K. Synlett 1999, 555. (b) Mehta, G.; Sreenivas, K. Tetrahedron Lett. 1999, 40, 4877. (c) Mehta, G.; Sreenivas, K. Tetrahedron Lett. 2001, 42, 2855.

7. (a) Mehta, G.; Sreenivas, K. Chem. Commun. 2001, 1892. (b) Mehta, G.; Sreenivas, K. Tetrahedron Lett. 2002, 43, 3319.

8. Plattner, J. J.; Bhalerao, U. T.; Rapoport, H. J. Am. Chem. Soc. 1969, 91, 4933.

9. Ito, Y.; Hirao, T.; Saegusa, T. J. Org. Chem. 1978, 43, 101.

10. For earlier synthesis of $\mathbf{6}$ and $\mathbf{9}$, see: Ref. 5a and Ohfune, Y.; Shirahama, H.; Matsumoto, T. Tetrahedron Lett. 1975, 4377. See also Fex, T.; Froborg, J.; Magnusson, G.; Thoren, S. J. Org. Chem. 1976, 41, 3518. Magnus, P.; Quagliato, D. J. Org. Chem. 1985, 50, 1621.

11. Ballini, R.; Marcantoni, E.; Petrini, M. Tetrahedron Lett. 1992, 33, 4835.

12. Ley, S. V.; Norman, J.; Griffith, W. P.; Marsden, S. P. Synthesis 1994, 639.

13. Mehta, G.; Vidya, R. J. Org. Chem. 2001, 66, 6905.

14. Servis, K. L.; Roberts, J. D. J. Phys. Chem. 1963, 67, 2885.

15. Irngartinger, H.; Reimann, W.; Garner, P.; Dowd, P. J. Org. Chem. 1988, 53, 3046. 